\title{
HUBUNGAN PENGETAHUAN LINGKUNGAN TERHADAP SIKAP DAN PERILAKU PEDULI LINGKUNGAN PADA SISWA SMAN 5 JEMBER TAHUN PELAJARAN 2018/2019
}

\author{
Evita Erryc Agustin ${ }^{1}$, Wiwin Maisyaroh ${ }^{1}$ \\ ${ }^{1}$ Institut Agama Islam Negeri Jember, Jl. Mataram No. 1 Mangli, Jember 68136, Jawa \\ Timur, Indonesia \\ E-mail: evitaerrycaa@gmail.com
}

\begin{abstract}
SMAN 5 Jember is a school that has received the Adiwiyata program predicate. Based on the phenomenon, students who have environmental knowledge do not necessarily have attitudes and behaviors that care about the environment. This is not in line with the school's goal of maintaining the status of a Adiwiyata school. The purpose of this study was to determine the relationship between environmental knowledge and environmental care and environmental care behavior among students of SMAN 5 Jember in the 2018-2019 academic year. This study uses a nonexperimental correlational quantitative approach using the ex post facto method. The population in this study were students of class X and XI, amounting to 480 students. The sampling technique used was proportionate stratified random sampling technique. Methods of data collection using observation, interviews, questionnaires and documentation. Data analysis used Kendall's Tau Correlation. Based on the results of the research on the relationship between environmental knowledge and environmental care attitudes in students of SMAN 5 Jember, the results obtained were $0.000<0.05$ so that $\mathrm{Ha}$ was accepted and $\mathrm{H} 0$ was rejected, meaning that there was a significant relationship. The relationship between environmental knowledge and environmental care behavior results in $0.532>0.05$ so that $\mathrm{Ha}$ is accepted and $\mathrm{H} 0$ is rejected, meaning that there is no significant relationship.
\end{abstract}

Keywords: Adiwiyata, Knowledge, Attitude, and Behavior

\begin{abstract}
Abstrak: SMAN 5 Jember merupakan sekolah yang mendapatkan predikat program Adiwiyata. Berdasarkan fenomena siswa yang memiliki pengetahuan lingkungan belum tentu memiliki sikap dan perilaku peduli lingkungan. Hal ini tidak selaras dengan tujuan sekolah mempertahankan status sekolah Adiwiyata. Tujuan penelitian ini untuk mengetahui hubungan pengetahuan lingkungan dengan sikap peduli lingkungan dan perilaku peduli lingkungan pada siswa SMAN 5 Jember tahun pelajaran 2018-2019. Penelitian ini menggunakan pendekatan kuantitatif korelasional non eksperimental menggunakan metode ex post facto. Populasi pada penelitian ini yaitu siswa kelas X dan XI yang berjumlah 480 siswa. Teknik pengambilan sampel dengan menggunakan teknik sampling proportionate stratified random sampling. Metode pengumpulan data menggunakan observasi, wawancara, angket dan dokumentasi. Analisis data menggunakan Kendall's Tau Correlation. Berdasarkan hasil penelitian hubungan pengetahuan lingkungan dengan sikap peduli lingkungan pada siswa SMAN 5 Jember diperoleh hasil 0,000 < 0,05 sehingga Ha diterima dan H0 ditolak artinya ada hubungan yang signifikan. Hubungan pengetahuan lingkungan dengan perilaku peduli lingkungan diperoleh hasil 0,532 > 0,05 sehingga Ha diterima dan H0 ditolak artinya tidak ada hubungan yang signifikan.
\end{abstract}

Kata kunci: Adiwiyata, Pengetahuan, Sikap, dan Perilaku

SMA Negeri 5 Jember adalah salah satu sekolah yang mendapatkan penghargaan Adiwiyata Tingkat Nasional tahun 2009 dan pada tahun 2010 mendapatkan predikat sebagai Sekolah Adiwiyata Mandiri yang diberikan langsung oleh Presiden Republik Indonesia ke-6 yaitu Susilo Bambang Yudhoyono. Adiwiyata mempunyai pengertian atau makna sebagai 
tempat yang baik dan ideal dimana dapat diperoleh segala ilmu pengetahuan dan berbagai norma serta etika yang dapat menjadi dasar manusia menuju terciptanya kesejahteraan hidup kita dan menuju kepada cita-cita pembangunan berkelanjutan. Tujuan program Adiwiyata adalah mewujudkan warga sekolah yang bertanggung jawab dalam upaya perlindungan dan pengelolaan lingkungan hidup melalui tata kelola sekolah yang baik untuk mendukung pembangunan berkelanjutan (KLH, 2011:3).

Struktur pembentuk sikap dipengaruhi oleh 3 macam respon yaitu cognitive responses (respon pengetahuan), affective responses (respon sikap), conative responses (respon perilaku/ kecenderungan) (Azwar, 2013:24). Pengetahuan yang diperoleh dalam kelas selama proses pembelajaran merupakan ilmu yang penting kita gunakan dan mengaplikasikannya dalam kehidupan sehari-hari. Sementara sikap (attitude) adalah kecenderungan yang relatif menetap untuk bereaksi dengan cara baik atau buruk terhadap orang atau barang tertentu (Muhibbin, 2006:123). Sikap ditafsirkan dari bentuk perilaku yang tampak. Dengan kata lain, untuk mengetahui sikap seseorang terhadap sesuatu kita dapat memperhatikan perilakunya, sebab perilaku merupakan salah satu indikator sikap individu (Azwar, 2013:90).

Memiliki sikap perilaku peduli lingkungan sangatlah penting karena baik buruknya kondisi suatu lingkungan juga ditentukan berdasarkan baik buruknya sikap dan perilaku manusia terhadap lingkungan (Hamzah, 2013:3). Lingkungan bagi manusia salah satu unsur yang sangat penting, karena lingkungan tidak saja sebagai tempat manusia beraktivitas, tetapi lingkungan juga sangat berperan dalam mendukung berbagai aktivitas manusia. Dengan adanya interaksi ini, maka dapat dipastikan bahwa kondisi lingkungan juga akan dipengaruhi oleh perilaku manusia. Sikap perilaku manusia akan menentukan baik buruknya kondisi suatu lingkungan. Sebaliknya, bagaimana manusia memperlakukan lingkungan dampaknya akan berpengaruh terhadap kualitas kehidupan manusia itu sendiri (Hamzah, 2013:1).

Pada dasarnya siswa yang memiliki pengetahuan lingkungan belum tentu memiliki sikap perilaku peduli lingkungan. Berdasarkan hasil observasi ketika magang 2 di SMAN 5 Jember pada bulan September-Desember 2018, terdapat siswa yang tidak bertanggung jawab dalam menjaga lingkungan kelas mereka dengan membuang sampah di kelas dan tidak pada tempat sampah, ada juga yang tidak melakukan piket membersihkan kelas ataupun piket menyiram tanaman dan pepohonan yang ada di sekitar kelas mereka. Pada jam istirahat ada juga yang berjalan tidak hati-hati, sehingga merusak tanaman yang ada di samping mereka, ada juga yang dengan sengaja memetik tanaman di sekitar mereka dengan alasan tanaman atau bunga itu bagus sehingga mereka ingin mengoleksi atau membawa pulang ke rumah atau hanya sekedar dibuat mainan. Hal ini tidak selaras dengan tujuan sekolah untuk mempertahankan 
status sekolah Adiwiyata. Berdasarkan pemaparan diatas, peneliti tertarik untuk meneliti "Hubungan Pengetahuan Lingkungan terhadap Sikap dan Perilaku Peduli Lingkungan pada Siswa SMAN 5 Jember Tahun Pelajaran 2018/2019”.

\section{METODE}

Penelitian ini dilaksanakan di SMAN 5 Jember sejak bulan September sampai Desember 2018 dengan menggunakan jenis penelitian korelasional non eksperimental dan metode $e x$ post facto. Populasi pada penelitian ini yaitu siswa kelas X dan XI. Teknik pengambilan sampel dengan menggunakan teknik sampling proportionate stratified random sampling. Menurut Sugiyono (2016:65) teknik tersebut efisien untuk mendapatkan data yang proporsional dan merata. Dalam menentukan sampel menggunakan rumus Isaac dan Michael dengan taraf kesalahan 5\% (Sugiyono, 2016:87) sehingga diperoleh 202 sampel dari 480 siswa dan teknik pengumpulan data yang digunakan yaitu melalui observasi, wawancara, angket dan dokumentasi.

Instrumen pengumpulan data penelitian berupa angket dan sebelum instrumen digunakan, dilakukan uji coba terlebih dahulu. Hal ini bertujuan untuk mengetahui soal yang diperlukan dan tidak sehingga diperoleh instrumen yang benar-benar handal. Uji validitas instrumen dilakukan untuk menunjukan keabsahan dari instrumen yang akan dipakai pada penelitian. Menurut Arikunto (2013:168), validitas adalah suatu ukuran yang menunjukkan tingkat kevalidan dan kesahihan suatu instrumen. Pengertian validitas tersebut menunjukan ketepatan dan kesesuaian alat ukur yang digunakan untuk mengukur variabel. Alat ukur dapat dikatakan valid jika benar-benar sesuai dan menjawab secara cermat tentang variabel yang akan diukur. Penghitungan uji validitas ini menggunakan bantuan Statistical Package for the Social Science (SPSS) V.22. Setelah diperoleh, kemudian dibandingkan dengan $\mathrm{dk}=\mathrm{n}-2$ $(\mathrm{dk}=202-2=200)$. Jika dilihat dalam nilai-nilai $\mathrm{r}$ Product Moment $=0,1161$. Jika $>$ maka item tersebut dinyatakan valid, dan jika $<$ maka item tersebut dinyatakan tidak valid.

Menurut Arikunto (2013:168) "Validitas adalah suatu ukuran yang menunjukkan tingkat kevalidan dan kesahihan suatu instrumen". Pengertian validitas tersebut menunjukan ketepatan dan kesesuaian alat ukur yang digunakan untuk mengukur variabel. Alat ukur dapat dikatakan valid jika benar-benar sesuai dan menjawab secara cermat tentang variabel yang akan diukur. Penghitungan uji validitas ini menggunakan bantuan Statistical Package for the Social Science (SPSS) V.22. Setelah diperoleh, kemudian dibandingkan dengan $\mathrm{dk}=\mathrm{n}-2$ $(\mathrm{dk}=202-2=200)$. Jika dilihat dalam nilai-nilai $\mathrm{r}$ Product Moment $=0,1161$. Jika $>$ maka item tersebut dinyatakan valid, dan jika < maka item tersebut dinyatakan tidak valid. 
Dari analisis yang dilakukan dengan SPSS For Window 22 didapatkan bahwa dari 24 soal yang ada pada angket tidak ada yang gugur. Hasil pengamatan pada rTabel didapatkan nilai dari sampel $\mathrm{dk}=\mathrm{n}-2(\mathrm{dk}=202-2=200)$. Jika dilihat dalam nilai-nilai r Product Moment, $=0,1161$. Sehingga merujuk pada hasil dari uji validitas dihasilkan bahwa semua instrumen mulai dari variabel pengetahuan lingkungan $(\mathrm{X})$, variabel sikap peduli lingkungan $\left(\mathrm{Y}_{1}\right)$, variabel perilaku peduli lingkungan $\left(\mathrm{Y}_{2}\right)$ semuanya menghasilkan nilai rHitung > daripada rTabel. Hal ini dapat ditarik kesimpulan bahwa semua instrumen dalam penelitian tersebut valid.

Uji reliabilitas dilakukan untuk mengetahui ketetapan suatu instrumen (alat ukur) didalam mengukur gejala yang sama walaupun dalam waktu yang berbeda. Menurut Sugiyono (2014:348) "Reliabilitas instrumen yaitu suatu instrumen yang bila digunakan beberapa kali untuk mengukur objek yang sama, maka akan menghasilkan data yang sama”.

Analisis data menggunakan statistik deskriptif dan statistik inferensial. Pada awalnya dalam penelitian ini peneliti berencana menggunakan analisis statistik parametrik product moment, tetapi karena distribusi data yang dihasilkan pada uji normalitas (Kolmogorov Smirnov) berdistribusi tidak normal maka peneliti menggunakan statistik non parametrik dengan uji korelasi Kendall-Tau. Kendall-Tau sering digunakan untuk menganalisis data yang semula direncanakan dianalisis dengan product moment dan memiliki jumlah sampel besar serta bebas berdistribusi (Azwar, 2009).

\section{HASIL}

Berdasarkan hasil uji Kendall's Tau Correlation diperoleh nilai sig variabel pengetahuan lingkungan dengan variabel sikap peduli lingkungan sebesar $0,000<0,05$ (Ha diterima dan H0 ditolak), artinya terdapat hubungan yang signifikan antara pengetahuan lingkungan dengan sikap peduli lingkungan. Sedangkan keeratan hubungan antara variabel pengetahuan lingkungan dengan variabel sikap peduli lingkungan memiliki hubungan yang rendah karena diperoleh hasil 0,310 yang terletak pada 0,20-0,399. Antara variabel pengetahuan dengan variabel perilaku peduli lingkungan diperoleh hasil yang tidak signifikan karena memiliki nilai sig 0,532 > 0,05 (Ha ditolak dan H0 diterima), artinya tidak ada hubungan yang signifikan antara pengetahuan lingkungan dengan perilaku peduli lingkungan. Sedangkan untuk keeratan hubungan antara variabel pengetahuan lingkungan dengan variabel perilaku peduli lingkungan diperoleh hasil 0,330 terletak pada 0,20 - 0,399 artinya keeratan hubungannya "rendah." 


\section{PEMBAHASAN}

Berdasarkan hasil analisis Kendall's Tau Correlation hasil uji hipotesis pertama bahwa antara variabel pengetahuan lingkungan dengan variabel sikap peduli lingkungan siswa kelas X dan XI SMA Negeri 5 Jember tahun pelajaran 2018/2019 diperoleh hasil 0,000 kemudian hasil ini dikonsultasikan dengan nilai signifikansi yaitu 0,05 maka dapat diartikan bahwa 0,00 $<0,05$ maka Ha diterima dan H0 ditolak artinya ada hubungan yang signifikan antara pengetahuan lingkungan dengan sikap peduli lingkungan, sedangkan keeratan hubungannya diperoleh hasil 0,310 yang terletak pada $0,20-0,399$ artinya keeratan hubungannya rendah dan terdapat hubungan positif.

Penelitian ini sejalan dengan penelitian yang dilakukan oleh Fauzi, dkk (2018) yaitu terdapat hubungan positif antara pengetahuan lingkungan hidup dengan sikap peduli lingkungan pada siswa SMA Negeri di Kabupaten Karanganyar, hal ini dapat ditunjukkan dengan besarnya korelasi antara variabel X1 dengan Y yaitu dengan hasil perhitungan rhitung sebesar $0.149>$ rtabel sebesar 0.137. Dalam hal ini dapat diputuskan bahwa pada hipotesis 1 telah teruji kebenarannya "Ada hubungan positif antara pengetahuan lingkungan hidup dengan sikap peduli lingkungan pada siswa SMA Negeri di Kabupaten Karanganyar”.

Seseorang yang memiliki pengetahuan tentang lingkungan yang bagus maka sikap dan perilaku peduli lingkungan yang diaplikasikan dalam kehidupan sehari-hari akan bagus, tetapi ketika seseorang memiliki sikap dan perilaku peduli lingkungan yang bagus belum tentu pengetahuan tentang lingkungannya bagus. Hal ini dikarenakan pengaplikasian sikap dan perilaku peduli lingkungan dalam kehidupan sehari-hari dapat diciptakan melalui pembiasaan sejak dini, baik itu dari lingkungan keluarga maupun dari lingkungan sekolah.

Menurut Azwar (2013:15) sikap merupakan predisposisi evaluatif yang banyak menentukan bagaimana individu bertindak, akan tetapi sikap dan tindakan nyata seringkali jauh berbeda. Hal ini dikarenakan tindakan nyata tidak hanya ditentukan oleh sikap semata namun juga ditentukan faktor eksternal lainnya. Banyak penelitian menunjukkan bahwa antara sikap dan perilaku itu tidak berkorelasi, ataupun bila berkorelasi maka tidak menunjukkan arah yang hubungan kausalitas. Sebagai penyebabnya karena sikap itu memiliki tiga komponen yaitu komponen kognitif, afektif, dan konatif (Azwar,2013:27).

Pengetahuan dan pemahaman siswa agar lebih tinggi tentang lingkungan, maka sangat tergantung dari situasi dan kondisi penyampaian materi, dalam hal ini guru dapat menggunakan metode yang tepat supaya murid tidak jenuh dengan materi yang disampaikan. Selain itu juga bisa melalui pengalaman-pengalaman yang diperoleh siswa selama dalam proses pembelajaran seperti pelaksanaan praktikum atau observasi lingkungan yang diadakan 
sekolah. Dengan demikian diharapkan siswa mempunyai pengetahuan yang lebih dan akhirnya dapat membentuk sikap dan perilaku yang positif. Di sekolah peran guru sangat penting dan perilaku kepedulian guru terhadap lingkungan akan menjadi ukuran keteladanan peserta didiknya.

Dalam interaksi sosialnya, individu bereaksi membentuk pola sikap tertentu terhadap berbagai objek psikologis yang dihadapinya. Ada beberapa faktor yang mempengaruhi pembentukan sikap yaitu; Pengalaman pribadi, Kebudayaan, Orang lain yang dianggap penting, Media massa, Institusi atau lembaga pendidikan dan lembaga agama dan Faktor emosi dalam diri individu (Azwar,2013:36).

Berdasarkan hasil observasi siswa-siswi SMA Negeri 5 Jember masih saja ada yang tidak peduli dengan lingkungan sekitar mereka seperti masih membuang sampah tidak pada tempatnya (membuang sampah kertas di bawah kolong meja, sampah kertas berserakan di lantai kelas), tidak mematikan kran air kamar mandi ketika sudah penuh, ada juga yang tidak melakukan piket menyiram tanaman yang ada di sekitar lingkungan kelas mereka. Pengetahuan tentang kepedulian lingkungan yang siswa dapat memang belum sepenuhnya diaplikasikan terhadap sikap dan perilaku peduli lingkungan hal ini menurut Notoadmodjo (2011:121) dikarenakan tingkat kesadaran mereka terhadap kelestarian lingkungan sekitar mereka masih berada dalam tahap memahami saja dan belum sampai pada tahap aplikasi.

Faktor-faktor yang mempengaruhi sikap menurut menurut Azwar (2013:30) yaitu pengalaman pribadi, pengaruh orang lain yang dianggap penting, pengaruh kebudayaan, media massa, lembaga pendidikan dan lembaga agama, dan faktor emosional hal ini yang mendasari mengapa seseorang ketika sudah mempunyai pengetahuan tetapi mereka belum memiliki sikap untuk selanjutnya berperilaku dalam menjalankan aktivitasnya.

Perilaku merupakan bentuk tindakan nyata seseorang sebagai akibat dari adanya aksi respon dan reaksi. Agiviana (2015) menyatakan bahwa peningkatan pengetahuan tidak selalu menyebabkan perubahan perilaku, tetapi pengetahuan sangat penting diberikan sebelum individu melakukan suatu tindakan. Tindakan akan sesuai dengan pengetahuan apabila individu menerima isyarat yang cukup kuat untuk memotivasi dia bertindak sesuai dengan pengetahuannya.

Berdasarkan hasil analisis Kendall's Tau Correlation hasil uji hipotesis kedua antara variabel pengetahuan lingkungan dengan variabel perilaku peduli lingkungan X dan XI SMA Negeri 5 Jember tidak diperoleh hasil yang signifikan karena nilai signifikansinya yaitu 0,532 kemudian hasil ini dikonsultasikan dengan nilai signifikansi yaitu 0,05 maka dapat diartikan bahwa 0,532 > 0,05 sehingga Ha ditolak dan H0 diterima artinya tidak ada hubungan yang 
signifikan antara pengetahuan lingkungan dengan perilaku peduli lingkungan. Keeratan hubungan antara variabel pengetahuan lingkungan dengan variabel perilaku peduli lingkungan diperoleh hasil 0,330 terletak pada 0,20 - 0,399 artinya keeratan hubungannya rendah dan terdapat hubungan positif.

Menurut Darmawan dan Fadjarajani (2016) menyatakan bahwa perilaku manusia tidak timbul dengan sendirinya, karena perilaku terjadi akibat stimulus yang diterima oleh manusia dari luar maupun dari dalam tubuhnya. Umumnya perilaku terjadi akibat gabungan stimulus dari dalam dan luar tubuhnya. Reseptor digunakan untuk mendeteksi stimulus, saraf diperlukan untuk mengkoordinasikan respon dan efektor untuk melaksanakan aksi. Perilaku yang muncul merupakan proses interaksi antara kepribadian dan lingkungan yang mengandung rangsangan (stimulus). Stimulus kemudian ditanggapi dalam bentuk respon. Respon inilah yang disebut perilaku. Perilaku ini ada yang nampak (respon dengan tindakan) dan tidak nampak (tanpa tindakan). Perilaku yang nampak, adalah perilaku yang dapat diamati oleh orang lain. Sedangkan perilaku yang tidak tampak, tidak dapat diamati secara langsung oleh orang lain, misalnya berfikir dan merasakan.

Berdasarkan hasil penelitian, hubungan antara pengetahuan lingkungan, sikap dan perilaku peduli lingkungan termasuk dalam kategori rendah hal ini dikarenakan faktor perilaku. Menurut Notoatmodjo (2011:115), perilaku dibedakan menjadi 2 yaitu perilaku tertutup (covert bahavior) dan perilaku terbuka (overt behavior). Perilaku tertutup yaitu respon seseorang terhadap stimulus dalam bentuk tertutup atau terselubung, respon terhadap stimulus tersebut masih terbatas pada perhatian, persepsi, pengetahuan atau kesadaran, dan sikap yang terjadi pada orang yang menerima stimulus tersebut belum dapat diamati secara jelas oleh orang lain.

Dari hasil angket perilaku peduli lingkungan dapat disimpulkan bahwa siswa SMAN 5 Jember masih dalam tahap tingkatan pertama yaitu pada perilaku tertutup karena mereka sudah memiliki pengetahuan tetapi mereka masih terbatas pada perhatian, persepsi, pengetahuan atau kesadaran, dan sikap yang terjadi pada orang yang menerima stimulus tersebut dan belum dapat diamati secara jelas oleh orang lain.

Rendahnya sikap dan perilaku peduli lingkungan akan menyebabkan ketidakseimbangan antara tujuan dari sekolah yang ingin menerapkan program Adiwiyata dengan sikap dan perilaku peduli lingkungan yang dimiliki oleh warga sekolah itu sendiri. Hal ini mungkin disebabkan kurang adanya kontroling atau ajakan untuk menjadikan program Adiwiyata itu tercapai tujuan dan sasarannya mungkin, sudah ada program-program untuk mewujudkan program Adiwiyata tersebut seperti, menanam pepohonan dan tanaman yang dapat mengu- 
rangi polusi udara dan membuat lingkungan sekolah menjadi lebih segar dan hijau, memilah sampah organik dan anorganik, membuat kompos dari sampah daun-daun. Akan tetapi mungkin yang terlibat dalam kegiatan tersebut hanya beberapa orang saja tidak secara menyeluruh.

Komitmen dalam mengemban predikat sebagai Sekolah Adiwiyata tingkat Nasional harus dipertahankan oleh sekolah. Dalam pelaksanaan program Adiwiyata, siswa memiliki peranan penting sebagai pelaksana kebijakan, sehingga harus senantiasa disosialisasikan dan dilibatkan dalam setiap kegiatan program Adiwiyata. Guru harus mampu menjadi contoh bagi siswa dalam rangka memelihara dan mengelola lingkungan sekolah. Mata pelajaran yang diintegrasikan dengan wawasan lingkungan sebaiknya disertai dengan praktek agar pengalaman belajar yang diperoleh lebih baik. Kerjasama antara seluruh warga sekolah memiliki peranan penting, sehingga koordinasi dalam kerjasama diperlukan untuk mencapai tujuan program Adiwiyata

\section{KESIMPULAN DAN SARAN}

\section{Kesimpulan}

Berdasarkan penelitian yang dilakukan pada siswa kelas X dan XI SMA Negeri 5 Jember tahun pelajaran 2018/2019 dapat diambil kesimpulan sebagai berikut: Ada hubungan positif antara pengetahuan lingkungan dengan sikap peduli lingkungan pada siswa SMAN 5 Jember tahun pelajaran 2018/2019 dengan diperoleh nilai sig 0,000 $<0,05$, sedangkan keeratan hubungannya diperoleh hasil 0,310 artinya keeratan hubungannya "rendah". Tidak ada hubungan antara pengetahuan lingkungan dengan perilaku peduli lingkungan pada siswa SMAN 5 Jember tahun pelajaran 2018/2019. dengan diperoleh nilai sig 0,532 <0,05, sedangkan keeratan hubungannya diperoleh hasil 0,330 artinya keeratan hubungannya "rendah".

\section{Saran}

Berdasarkan hasil penelitian, pembahasan dan kesimpulan, maka peneliti memberikan saran sebagai berikut: diharapkan bagi siswa untuk memperbanyak pengetahuan mengenai lingkungan sehingga dapat memberi pengaruh yang lebih terhadap sikap dan perilaku peduli lingkungan. Diharapkan kepada bapak dan ibu guru untuk memberikan pengetahuan lingkungan yang lebih banyak kepada siswa yang dapat mendorong meningkatnya sikap dan perilaku peduli lingkungan yang dimiliki siswa. Diharapkan kepada pihak sekolah untuk memberi wadah serta mendorong kegiatan-kegiatan yang berkaitan mengenai lingkungan hidup sehingga dapat mendorong sikap dan perilaku peduli lingkungan yang dimiliki siswa lebih meningkat. Berdasarkan data penelitian yang menunjukkan tingkat perilaku peduli lingkungan 
maka perlu dilakukan penelitian lanjutan dengan menggunakan pendekatan kualitatif mengenai faktor-faktor yang menyebabkan rendahnya tingkat perilaku peduli lingkungan pada siswa SMAN 5 Jember tahun pelajaran 2018/2019. Bagi peneliti selanjutnya diharapkan untuk melakukan penelitian yang berbasis gender artinya apakah ada perbedaan antara perempuan dan laki-laki dalam tingkat pengetahuan lingkungan, sikap dan perilaku peduli lingkungan.

\section{DAFTAR RUJUKAN}

Agiviana, Anisa Putri. Analisis Pengaruh Persepsi, Sikap, Pengetahuan dan Tempat Kerja Terhadap Perilaku Keselamatan Karyawan. Skripsi. 2015. Fakultas Ekonomika dan Bisnis Universitas Diponegoro : Semarang.

Azwar, Saifuddin. 2013. Sikap Manusia. Yogyakarta: Pustaka Pelajar.

Darmawan, Darwis, Siti Fadjarajani. 2016. Hubungan Antara Pengetahuan Dan Sikap Pelestarian Lingkungan Dengan Perilaku Wisatawan Dalam Menjaga Kebersihan Lingkungan (Studi di Kawasan Objek Wisata Alam Gunung Galunggung Desa Linggajati Kecamatan Sukaratu Kabupaten Tasikmalaya). Jurnal Geografi. Volume 4 No: 1.

Fauzi, M Ichwan. Hubungan antara Pengetahuan Lingkungan Hidup dan Prestasi Belajar Geografi dengan Sikap Peduli Lingkungan pada siswa SMA Negeri di Kabupaten Karanganyar. Jurnal Geografi Ekonomi. Vol. 4, No. 1 (Januari 2018) Hal. 88-99.

Hamzah, Syukri. 2013. Pendidikan Lingkungan Sekelumit Wawasan Pengantar. Bandung: Refika Aditama.

Kementrian Lingkungan Hidup. http://www.menlh.go.id/informasi-mengenai-adiwiyata/. Diaksses oline pada tanggal 12 Maret 2019 pukul 19.58 WIB.

Notoadmodjo, Soekidjo. 2010. Ilmu Perilaku Kesehatan. Jakarta: PT. Rineka Cipta.

Notoadmodjo, Soekidjo. 2011. Pendidikan dan Perilaku Kesehatan. Jakarta: PT. Rineka Cipta.

Sugiyono. 2016. Cara Mudah Menyusun Skripsi, Tesis, dan Disertasi. Bandung: CV. Alfabeta.

Sugiyono. 2016. Metode Penelitian Kuantitatif, Kualitatif, dan R\&D. Bandung: CV. Alfabeta.

Suharsimi, Arikunto. 2002. Prosedur Penelitian Suatu Pendekatan Praktek. Jakarta: PT. Rineka Cipta.

Syah, Muhibbin. 2011. Psikologi Pendidikan dengan Pendekatan Baru. Bandung: Remaja Rosdakarya. 
Tim Penyusun. 2018. Pedoman Penulisan Karya Ilmiah IAIN Jember. Jember: IAIN Jember Press. 